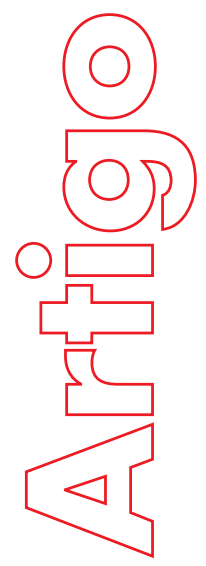

\title{
SPACE, TIME AND NATURE: THE PROCESS AND THE MYTH
}

\author{
Marília Luiza Peluso \\ Wallace Wagner Rodrigues Pantoja \\ Pâmela Elizabeth Morales Arteaga \\ Maxem Luiz de Araújo
}

p. $01-23$

\section{revista}

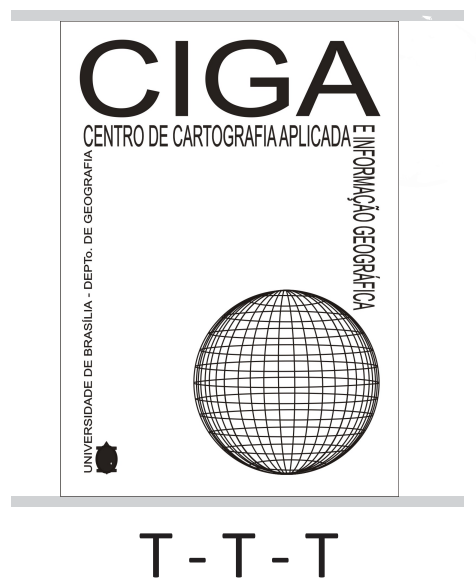

Eletronic Magazine: Time - Techinique - Territorry V.6, N.1 (2015), 1:23 ISSN : 2177-4366

DOI: https:// doi.org/10.26512/ ciga.v6i1.20918
Como citar este artigo:

PELUSO, M. L., Wallace Rodrigues Pantoja, Pâmela Elizabeth Morales Arteaga, Maxem Luiz de Araújo. Space, Time And Nature: The Process And The Myth. Eletronic Magazine: Time - Techinique Territorry, v.6, n.1 (2015), p. 1:23 ISSN: 2177-4366.

DOI: https://doi.org/10.26512/ciga.v6i1.20918

Disponível em:

http://periodicos.unb.br/index.php/ciga/

Este obra está licenciado com uma Licença Crea tive Commons Atribuição-Não Comercial 4.0 Internacional. 


\title{
SPACE, TIME AND NATURE: THE PROCESS AND THE MYTH Marília Luiza Peluso
}

Doutora em Psicologia, Professora da Pós-Graduação em Geografia/Departamento de Geografia/UnB.

Email: peluso@unb.br

\section{Wallace Wagner Rodrigues Pantoja}

Doutorando em Geografia (UNB), Mestre em Geografia (UFPA), Professor da Rede Estadual de Ensino do Pará.

Email: demithri@yahoo.com.br

\author{
Pâmela Elizabeth Morales Arteaga \\ Mestranda em Geograf ia (UNB), Psicóloga (Universidad SEK-Chile). \\ Email: pamela.morales.a@gmail.com
}

\section{Maxem Luiz de Araújo}

Especialista em Educação Ambiental, Professor do IFB Campus São Sebastião.

Email: maxemluiz@gmail.com

\begin{abstract}
ABSCTRACT: The article fits into the debate regarding space, time and nature in dialogue with the world lived by subjects that build up themselves or are built as mythological heroes, source of speech and spacial concrete practices. It's a poorly explored field in Geography that recently approaches to the cultural dynamic debate, to the symbolic field and also to their spacialization processes. The aim is to discuss the possibility of understanding in the present time about the space organization processes related to the society's previous moments, in a space/time dialectics which articulate the present and past times in a complex and non linear way. Methodologically, starting from a literature review about the theme, the present study was linked to the field and documental research about migration to the vicinal ways of Transamazônica Highway (BR-230 Highway), the creation of the "Centro Espírita União do Vegetal", a religion that arises in the Amazon and set up its headquarters in Brasília and the construction of Brasilia as a modern metropolis without a past. The conclusion points at the possibility of space/time nexuses linking the Myth of Nature to the Creation of Heroes, constantly appropriated and with new meanings, in order to support speeches and new actions dialectically throughout the Brazilian contemporaneous space.
\end{abstract}

Keywords: Dialectic space / time. Mythological geography. Nature. Modernity. 
RESUMO: O artigo se insere no debate entre espaço, tempo e Natureza em diálogo com o mundo vivido pelos sujeitos que se constroem ou são construídos como heróis mitológicos, fonte de discursos e práticas espaciais concretas. Um campo ainda pouco explorado na geografia que, mais recentemente, vem se aproximando do debate da dinâmica cultural, o campo simbólico e os processos de espacialização. O objetivo é discutir a possibilidade de compreensão no presente da organização do espaço em ligação com momentos anteriores da sociedade, numa dialética espaço/temporal que articula o presente e o passado de maneira complexa e não linear. Metodologicamente, partindo de uma revisão bibliográfica da temática se articulou à pesquisa de campo e documental sobre a migração para as vicinais/ramais na Transamazônica (BR-230), a criação da religião Centro Espírita Beneficente União do Vegetal, que surge na Amazônia e estabelece sua sede em Brasília e a construção de Brasília como a Metrópole moderna sem passado. A conclusão encaminha a possibilidade de nexos espaço-temporais, vinculando o mito da Natureza à criação de heróis, constantemente reapropriados e ressignificados para engendrar discursos e novas ações, dialeticamente, no espaço contemporâneo brasileiro.

Palavras-chaves: Dialética espaço/tempo. Geografia Mitológica. Natureza. Modernidade.

RÉSUMÉ: L’article fait partie du débat entre l'espace, le temps et la nature, mis en dialogue avec de sujets qui se construisent ou qui sont construits comme des héros mythologiques - source des discours et des pratiques sociales concrètes. Comme un sujet peu abordé, ce thème-là vient de se rapprocher du débat de la dinamique culturelle, le domaine symbolique et des processus de spatialisation. L'objectif, c'est de discuter la possibilité de comprendre, au présent, l'organisation du space en le reliant aux moments précédents de la societé, par la voie dialectique space/temps qui associe le present et le passé du façon complexe et non linéaire. En concernant la méthodologie, après la révision bibliographique on avait fait une recherche de terrain et des documents sur la migration pour les vicinaux de la Transamazonica (BR-230), la création de la réligion Centro Espírita Beneficente União do Vegetal (qui a été crée dans l'Amazonie et qui a établie la siège à Brasilia) et la construction de Brasilia comme Métropole moderne sans passé. La conclusion se dirige vers la possibilité de liens space-temps, en associant le mythe de la nature avec la création des héros, qui sont constamment dotés de nouvelles appropriations et significations pour entraîner, d'une façon dialectique, des discours et nouvelles actions dans l'espace contemporain brésilien.

Mots-clés : dialectique space-temps ; géographie mythologique ; nature ; modernité.

\section{INTRODUCTION}

In the social division of modern scientific work, occurred in the late nineteenth century and early twentieth century, geography was responsible for that vast territory located between society and nature. The delimitation of such an extensive field of knowledge earned it the designation by 
Foucault (1983) of "unclassifiable science”. On the other hand, such a vast field allowed it theories that cover multiple domains to understand how its subject matter - space and spatiality - is organized.

The study of geographical space in its various manifestations, however, requires an archeology that constantly shows us the past, to understand it in its modernity. Vidal de La Blache already pointed to the importance of the past to understand the present and the "incessant reactions of geography on the history and the history on geography” (LA BLACHE cited by Haesbaert et al, 2012, p. 67). Thus, it can be said that the geographical knowledge is developed around two fundamental concepts, society and nature, considering the time, because the space, as Santos writes (1990), is the accumulation of time. Moreover, it can be assumed that space and time can promote reflections on the sphere-world and allow intensely deepen about a reality that challenges the researcher.

Seeking a challenging thinking about the reality thought through time, society and Nature ${ }^{1}$ in its many manifestations and concealments was organized the course "Espaço em Geografia: uma revisão temporal” (Space in Geography: a temporal review) ${ }^{2}$, from which this article is the product. The aim was, and remains in the text that follows, lead to understand that the present organization of space is linked to earlier moments of society, in a dialectic space/time that links the present and the past in a complex and non-linear way. There was a question to be answered and formulated as follows: how the past remains in the present giving new meaning to time and space? The hypotheses of the course, and that guided reflections were in order: first, that space and time must be considered as a totality established upon insertion of the men in a pre-existing world; second, that the spatial and temporal totality is established in the joint of structures (instances) and material and non-material practices of society.

The central idea developed in the course was in Althusser (1978, p. 70), quoting Marx in 18 Brumário (18th Brumaire):

Men make their own history, but they do not make it just they please; they do not make it under circumstances chosen by themselves, but under circumstances directly encountered, given and transmitted from the past. ${ }^{3}$

\footnotetext{
1 The word "nature" is sometimes written with a capital letter and other lowercase. "Nature" refers to the mythical environment that challenges men; "nature" is the environment taken by the technical and science and therefore devoid of mysteries and perfectly knowable with more studies and more research.

2 The course was held in the 1st half of 2014, in the optional subject "Tópicos Especiais em Geografia” (Special Topics in Geography”, in the Postgraduate program in Geography, at the University of Brasília/UNB. “Tópicos” is a fairly free discipline and addresses issues of interest to the teacher and the students, looking to bring new theoretical approaches to the research projects developed by students of doctorate and master degree.

${ }^{3}$ Translator Note (TN) - All direct quotes were freely translated into English by the translator.
} 
The discussions started from Althusser and the "Subject of history", whose dynamics is in the class struggle, but over the course reached the "concrete subjects" and their lived stories, their relationship with nature and with other men, their contradictions and intentions. Thus, it was brought to the surface the most ancient and profound form of social knowledge, the myth, and also the actor of myth, the hero. But here, myths are reinterpreted and acquire a critical tone to unravel the lived of modernity that they claim to hide.

The argument that developed during the course will be presented here in five topics. In the first, there is a small theoretical reflection about the subject approach to geography that will forward the analysis of three specific situations narrated as follows: Amazonia torn by Trans-Amazonia - its myths and its heroes pioneers of the forest; from Amazonia comes to Brasilia, based in the city of modernity myth, but that does not refuse messiahs and heroes that bring with them a mythical time that if researched, has its origins in the Amazon rainforest; in Brasilia, is the construction of the Capital of the country that is in the game of myth and modernity and the refusal of a time and a space of the past. In the first two narratives is found the concrete subject, which does not let him(her)self be excluded and acquires the position of "hero" when infiltrates the interstices of the official narrative; the third narrative, past subject and time are suppressed for arising rationality of a desecrated world. In the conclusion we propose new discussions for geography about subjects and their trajectories.

\section{1 - SHORT THEORICAL REFLECTION: GEOGRAPHY WITHOUT SUBJECT?}

Geography, as modern science is concerned with study space and spatiality in its various manifestations. However, the idea of space came long before becoming a category of thought and a geographical concept. The spatiality as way to understand the world comes from very ancient knowledge built over the history of mankind and that is lost in time and is recreated every new moment of social practices and ways to produce. The knowledge expands, creates new themes, breaks and contradictions, defines meta-narrative, and produces new meanings to the surrounding reality.

It can be said that adapting the challenge of Nature and the other men, uncertainly enemies or friends, through geographical knowledge is very old and primitive tribes already described their journeys in the materials available to them. It was an intuitive knowledge and common sense, but able to show the difference between places and to allow the location and check the distances, to identify hazards and to find the resources necessary for survival. 
According to Neumann (1995), "From where? How? Why?” were the questions that men have done collectively, from ancient times, about their position in the world and the principle of things. The answers - also collective - have built practical knowledge for the problems and the challenges of life. The development of techniques was one of the answers to the domain of Nature and enemies. The other was the development of a symbolic system that mythically, told the story of the struggle for that domain, in which the hero represented the slow burst of reflective thinking (NEUMANN, 1995), the separation of nature and the Other differences (Peluso, 2003). “The hero”, writes Campbell (2014, p. 131), "is someone who gave his or her life to something bigger than oneself”, in a spiritual feat in which "learns to deal with the higher level of human spiritual life, and returns with a message”.

In ancient times the geographic knowledge was part of cosmogonies and the different visions of the world, with which deepened awareness of the difference between the places, from the narratives of travelers, location tool, maps and astronomy. A knowledge that, even though intuitive, sought the first explanation and systematization using the philosophy to explain the differences and similarities, the reasons and motives; ratings, harmony and imbalance of Nature and man.

In the Middle Ages, the geographical knowledge were within the religious sphere, the search for utopias, of the holy places, the establishment of the kingdom of God, but also formed a practical knowledge that studied the differentiation of places, the precise locations and distances, using astronomy, the coordinate system and projections, useful for land and sea trade routes and improved farming practices. The knowledge proceeded from many places, were told by many voices, with different discursive practices and aimed at multiple social practices (Foucault, 1987), encompassed under the general name of "Earth knowledge" - Geo-graphy.

The new positivity system that emerges in the eighteenth and nineteenth centuries, linked to the rise of industrial project, has given new meaning to the knowledge produced previously, including geographical knowledge. Four basic postulates have been imposed: first, the rule of reason; second, the desecration of the world; third, the use of nature for human purposes; and fourth, faith in progress (MENDOZA et al, 1982).

Geography, according to the new positive aspects and its new delimited territory, touted the previous geographical knowledge and formed systematized to the multiple, blurring breaks, discontinuities and contradictions. Thus a meta-narrative of the earth sciences and sciences of society emerged, a meta-narrative of the orderly relations of society and nature.

On a positive science, geography followed two paths: the first was to pull away from nature and also of human nature, seeing both as a subject and resource and therefore exploitable, quantifiable, predictable and manageable. The second was to emphasize the small scale, looking 
from the outside and from afar, even when was large scale, at the time that suppresses the knowing subject and replaces it with facts and events, processes and structures, laws and models in which the subject disappears.

The problem is that the elided subject insists on existing. Claval (1999) states that in postmodern epistemology man as an abstract entity no longer exists; we study men and their differences by gender, age, natural environment and the social environment in which they evolve. Claval (1999) continues writing that man is a being shaped by existence, memories and representations, seized in a particular context and life material belonging to a society and a particular and historical time.

The contradiction settles in geography: on one hand, an increasingly objective view, more technical, more impersonal of over-flight, on the other the elided subject in its existence, forcing the transition to geographical knowledge. And with the subject, its myths and its heroes who survive in memories and representations.

In the following three studies, the geographic space is not only seen as a product of objective knowledge, but also as a symbolic knowledge and representation of lived space. This space, the myth and the heroes return and re-signify spatiality on a path that follows from the Amazonia to Brasilia.

\section{2 - THE (TRANS) AMAZONIAN SAGA - MYSTIFICATION AND EXISTENCE}

The figure of the hero lends itself to almost endless interpretations, however, can essentially be understood as "the founder of the new" (Campbell, 2013, p. 145). This foundation can be mobilized as the legitimization argument in the Weberian sense, “obedience to a certain order” (Weber, 2005, p. 3) given by the living or transcendent sovereign heeded as sacrificial act by the vassal that, to a certain extent assimilates heroism in himself. Another aspect to the new foundation supposes the great journey, in ways never split, the pilgrimage to the ends of the world (ELIADE, 1992) seeking seed or grail (Campbell, 2013) that will make the new come into existence.

It is impossible to think the construction of the Trans-Amazonian Highway and the massive migration of Northeastern correlated to it, without grasping the link between founding representation of the new, sacrificial exercise and the occupation beyond the "Earth" borders. The strictly technical issues or restrictively political and economic will not be discussed here, although we will not disregard them. Interests us attending to the constitution of a spatial experience that at 
the same time produces and is the result of a mystification of existence, without which existence itself in Trans-Amazonian conditions would be unbearable, as it was in fact for many.

It should be noted that we are not here endorsing one self-referential "heroism" in the occupation process of the Trans-Amazonian front that begins in Cabedelo, Paraíba (in eastern Brazil, near the Atlantic), and ends, in theory, in Lábrea, State of Amazonas (AM), whose original project would go to Benjamin Constant, also in the AM, bordering Peru, where it could reach the Pacific Ocean. We propose to work with

The "Invention of the Trans-Amazonian", whose idea emerged in the late 1960s and which was established in an area already inhabited by indigenous people, rubber tappers, small and large traders, and farmers. It was, however, treated by the military government as a road that was being opened in an empty space of men and women, land to be conquered and colonized. Among other stories of violence committed in its implementation we still hear, today, whispered reports of fragments, about the genocide committed against the indigenous people that populated the ancient city of Altamira, which were tied to tractors advancing on the jungle . (Silva cited by Maues, 2012, p. 41, highlights by the author).

It is a story of terror and destruction. The new space was produced on previous space conditions, established relationships and that are broken down not only by the violence of State, but by a conception that unites faith and reason, sacrifice and opportunity, emulating certain messianism of northeastern base, but not exclusive to it which turns out to be potentiated by State inculcation of a "land without men", virgin to be dominated, in which the hero has something tragic and terrifying (Campbell, 2013).

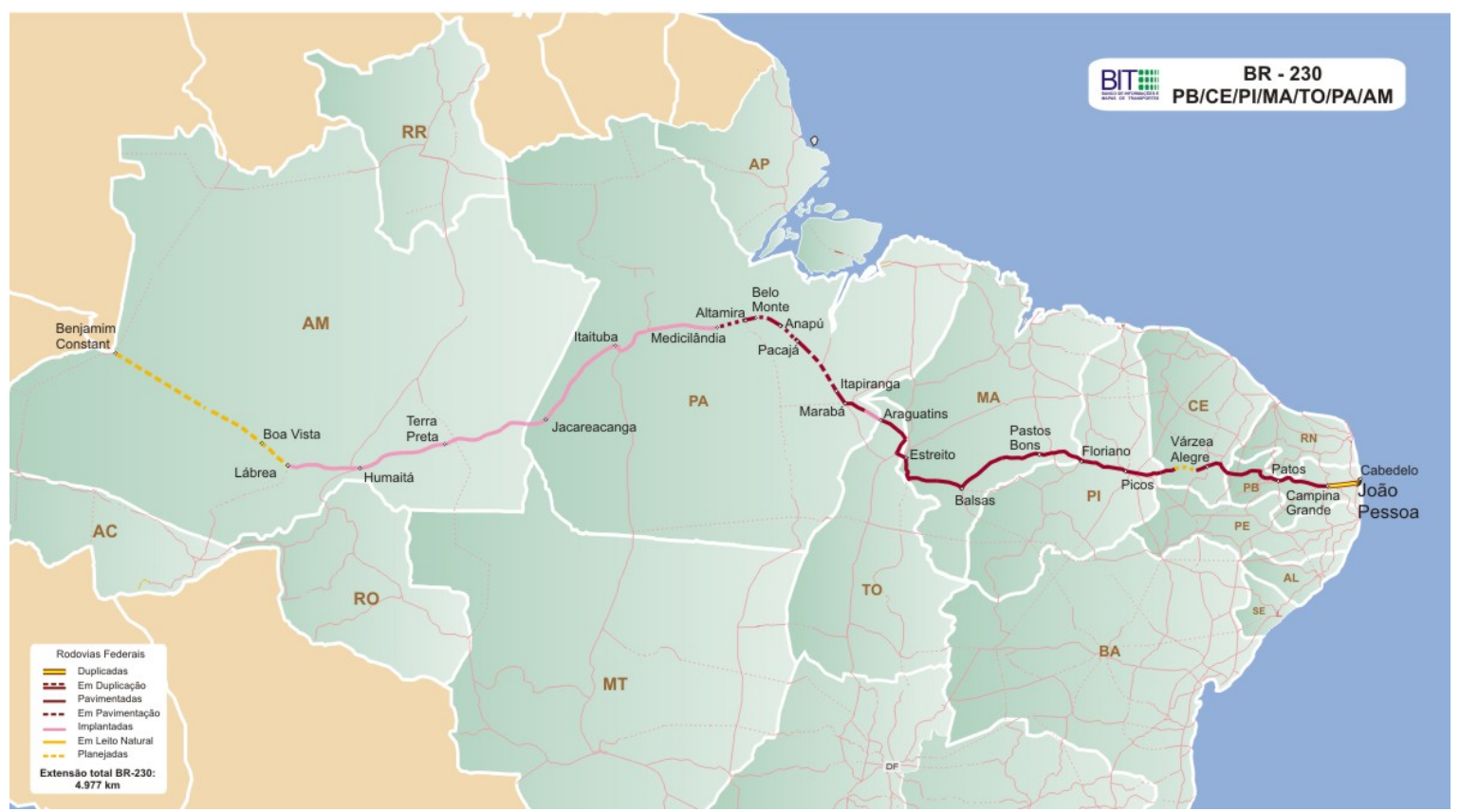

Map 1 - Trans-Amazonian Highway (BR-230), without scale. Source: Information Base and Transport Maps of Ministério dos Transportes, 2014.

2.1. Design and Pharaonic Conception - from the Atlantic to Pacific 
Euclides da Cunha (1904) has announced the need for administrative systems in northeastern occupation process of Amazonia, resuming discussions of the late nineteenth century. Cunha (1904) defined the Amazonian region as "land without history" and those who were going there as "expats in their own homeland", echoes of a past that will be assimilated by the State drastically.

The project for the construction of the Trans-Amazonian Highway - BR-230 - was astounding, not to say impossible - considering that was never finished - and Northeasterners were summoned to occupy the new land through the "gash" that the road would do not unreasonably, among residents of vicinal or small roads that leave from the Trans-Amazon into the forest. The term "The Strip" is used to designate the road.
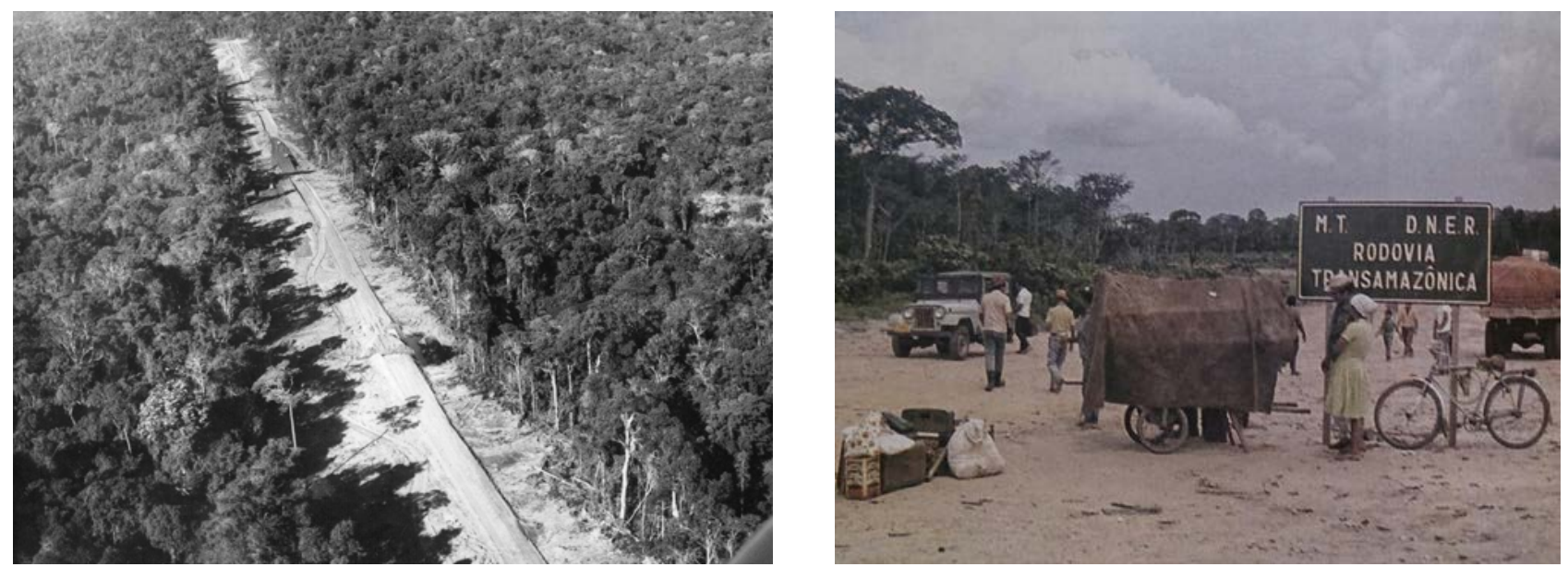

Photo 1 - Opening of the Trans-Amazonian, 1971. Source: www.exposicoesvirtuais.arquivonacional.gov.br Figure 1 - Northeastern arrival by the newly open road. Author: Oswaldo Maricato/Editora Abril. Source: VESENTINI; VLACH. Geografia Crítica, 2009.

Its construction dates back to the year 1971 and brought whole families that came from the northeast already in this period and over the years 1970 and 1980 to occupy the land and make history conceived as nonexistent. The Trans-Amazonian Project was not restricted to the region, neither to geography, as pointed out by Souza (2010 p. 7) when wrote that

The road to cross Brazil and join the Atlantic to the Pacific also raised intense debate among writers, enabling us interesting source for analysis, not only about the TransAmazonian Project, as well as how public health policies were elaborated and re-elaborated and which elements justified and/or were present in speeches about them. Speeches by different paths, ideas or sources dialogued on an elaborated project to national and international reach of Amazon with the integration of Brazil to the Pacific.

"Integration", here is the magic word and as such it demanded men who were ready to sacrifice, not only for themselves but also for the national project. But if on one hand the State speech repeatedly summoned the "anonymous heroes" - the "soldiers of the rubber" is only one of the possible examples of an earlier story - on the other hand this act of convocation would meet the 
need of the northeastern men and in addition to their material needs, their world of representations inseparable from a spiritual transcendence.

2. 2. Places of Life, Project Failure? From the perception to the representation in shock

Three northeastern people, now living in back roads - Vicinal of Ladeira da Velha and Vicinal of Portel - belonging to the municipality of Pacajá, Pará, crossed by Trans-Amazonian Highway, their founding spatiality, narrate their clearing paths of the unknown

We were from [we were in] Maranhão, but we heard there was good here [TransAmazonian of Pará] (...) We were informed about the lands that INCRA was giving, they were giving plots for everyone. Then I, too needy, as there I lived without too poor (...) then I learned to run back and forth (...). In seventy-seven I arrived here in Pacajá. ${ }^{4}$

Here life was too hard, we went in small forest trails, sometimes we spent three days to arrive in Pacajá (...), we used to go there just for shopping and we returned home (...) I’m not sure, but my father in law was the first to come here, by the small tracks [opening the virgin forest with a machete to create a possible path]. ${ }^{5}$

My life's work in the fields, all the time, I have no other profession. Then the person from the country likes new land, likes woods to work. ${ }^{6}$

These narratives represent the narratives of others, and bring significant elements for the purposes of this article: Need - "I lived too poor"; Sacrifice - "we went in small forest trails", "sometimes we spent three days"; New land - "woods to work". Such individualized perceptions establish a collectivized representation, or rather inter-subjective (MERLEAU-PONTY, 1999): the Trans-Amazonian saga is made of necessity, sacrifice and clearing the "Promised Land" (ELIADE, 1992).

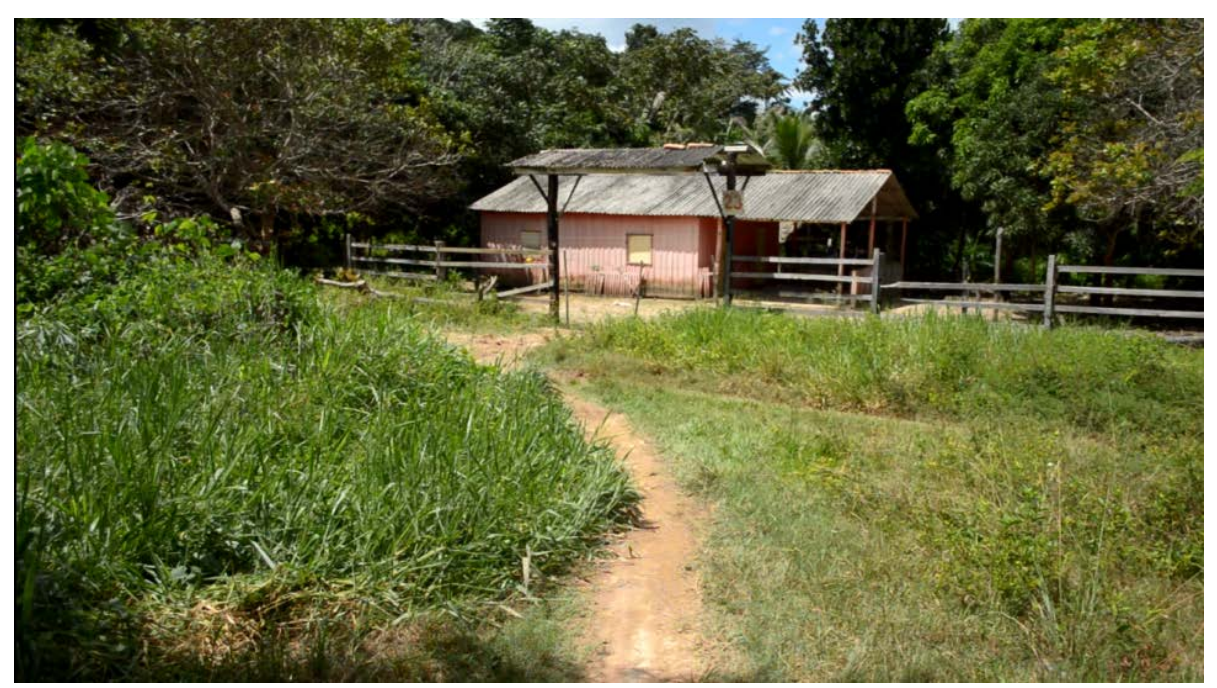

\footnotetext{
${ }^{4}$ João Mateus Francisco, 63 years old, born in Ceará. Interview: April/2013.

${ }^{5}$ Auricelia Lopes da Silva, 31 years old, born in Maranhão. Interview: May/2013

${ }^{6}$ Antônio Alves de Souza, 54 years old, born in Maranhão. Inverview: May/2013
} 
Photo 2 - Entrance of Vicinal of Portel, Pacajá (PA). Author: Cleison Nazaré, 05/2013.

However, this representation confronts with reality. The unsung heroes, transformed into faceless mass in the plans for a new space (NAHUM, 2011), have an inescapable concrete existence and, while existing, try to (re)produce from the triad - Need, Sacrifice and Promised Land - their living places.

Such reproduction is not just a future exercise, but inescapably, a reinvention of the preexisting places, meals, speech, devotions and religious affiliations, the arrangement of materiality reveal it - but the sacrifice is constant, and is endless: from an indomitable "Nature", where death by malaria is only one of many extreme situations (Jaspers, 1993), or the Other (traditional and/or contemporary) to the speech changes of a State which before encouraged them to deforest and now blame them for the same act (HONDA; SÊPEDA FILHO; PANTOJA, 2013).

This process is difficult to grasp, as pointed out by Figueiredo (1993, p. 15):

This standard self-contradictory [three axes: the liberal, the romantic and the disciplinarybureaucratic, that manifest in the territory of ignorance, in psychological terms, but not exclusive to this discipline] establishes as a cognitive decree; from any of the possible places of this space, there will always be parts of this territory protected in the shadows.

Along with other human sciences, geography should perhaps devote more and more of these dark parts, including understanding the contemporary Amazonia, but without losing sight of that the shadows are, exciting and fundamentally, part of the sacrificial heroism and of the new to be discovered, always fleeting.

Contradictory and elusive processes, difficult to grasp, but which originate other processes in which anonymous and faceless heroes recreate in the forest and illuminate the new territory of "Nature" and men, where the sacred, the myth and the symbol are integrated in urban modernity.

\section{3 - HERO AND NATURE - THE TERRITORY-NET AS CONDITIONING CREATOR OF SACRED TIME}

The space-time compression is changing the acceleration of global processes and the "reordering of distance" that seem to shorten when processes that occur in one place have immediate effect in another place or another territory (Hall, 2004, p. 23). There are processes that, from time to time, mark a path that transcends the individuals, their age or their culture, especially in times of acceleration and expansion of networks when the communication of their trajectories reaches territories and distant groups. In this sense, the trajectory taken by an individual for his courage and his mission can be defined here as "hero" will be analyzed. In Campbell's words (2003, p. 17) 
A hero ventures forth from the world of common day into a region of supernatural wonder: fabulous forces are there encountered and a decisive victory is won: the hero comes back from this mysterious adventure with the power to bestow boons on his/her fellows.

The hero in question is "Mestre Gabriel” (or Master Gabriel), who left the city of Coração de Maria, in the interior of Bahia, passing through Porto Velho (RO), to achieve its trajectory in Brasilia (DF). The mission can be summarized in the Master search for reconnecting human beings to God and their own spirituality. Mestre Gabriel is the founder of "União do Vegetal”7, so his history - regardless of any court - is considered a sacred history by the religious group that welcomed his messianism, with specific elements that characterize it as "reality that starts at a primary time and (re) signifies in today’s time”. (ELIADE, 1972, p. 11).

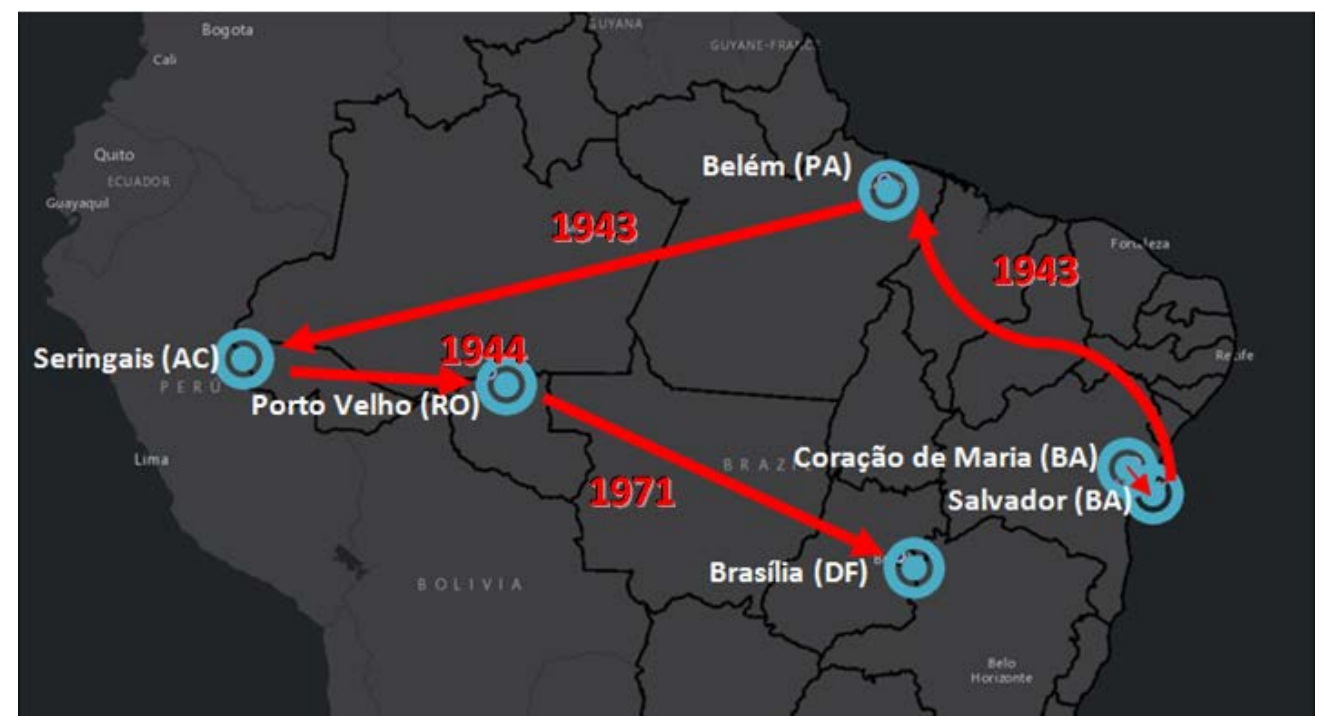

Map 2 - Gabriel Paths, from Coração de Maria to Brasilia, without scale. Authors: Pantoja, Arteaga and Cabral, ODR, 2015.

At 20 years old Gabriel leaves Coração de Maria toward Salvador, Bahia, looking for new opportunities; works in different small activities without fixed point. He was aware that his spiritual mission would take him away from those places. On his way, Gabriel tried various religions. One was the "Terreiros" of Candomblé, seeking a representation (and replay) of reality. However, nothing satisfied him in the spiritual quest to reconnect man to God. In his autobiographical words: "I have been through many religions, looking for a way to help humanity, to take the evil of people’s hearts - but did not find. I found this way only in the Vegetal”. (FABIANO, 2012, p. 37).

In incursions in the "Terreiros", Gabriel was recognized as the "Sultão das Matas” (Sultan of Forests). Not yet knowing that his future would take place inside the Amazonia, he goes into the unknown (FABIANO, 2012, p. 45). As Campbell writes (2003, p. 42): “Once having transversed

\footnotetext{
${ }^{7}$ The oficial name is "Sociedade Espírita Beneficente União do Vegetal” (União do Vegetal Spiritualist and Charitable Society).
} 
the threshold, the hero moves in a dream landscape of curiously fluid, ambiguous forms, where he must survive a succession of trials”

With his clear mission: help people and guide them along the path of good, Gabriel crosses space-barriers, leaving his symbolic mark in the territory he ran. Known as the "Sultan of the Forests”, from Bahia, confident in himself and true to his destiny - utopia for some, foolishness to others - comes to the current state of Acre, then still a territory, as one of thousands of northeastern men transformed into "Soldiers of the rubber".

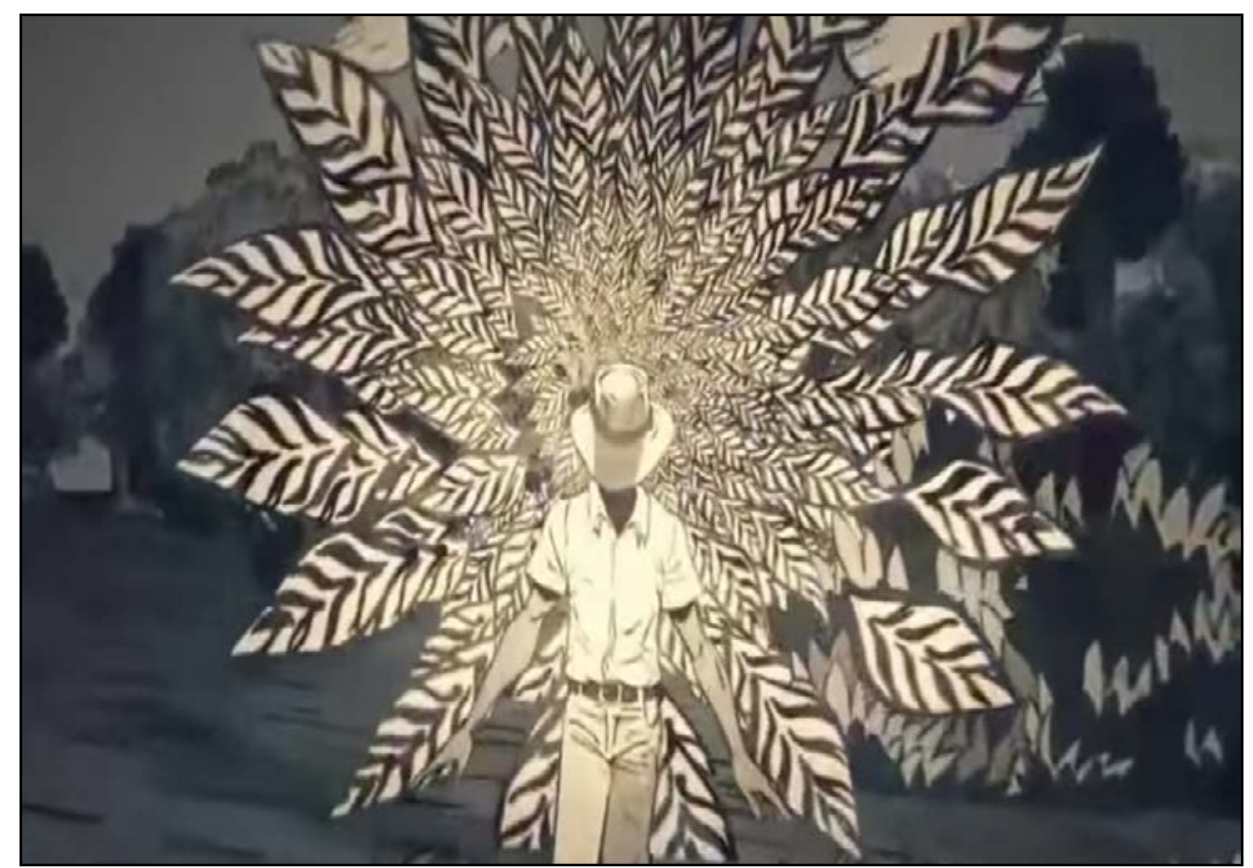

Figure 2 - Gabriel “Sultão das Matas”. Source: DMD-SG -blog of UDV

Acre is the key to his quest, from the union of two plants - Mariri (Banisteriopsis caapi) and Chacrona (Psicotria viridis) - is prepared the Hoasca tea, as called by the Amazonian caboclos (mestizos). Gabriel, now "Master", combining elements from the Amazonian caboclos culture to the saga of a hero, he viewed himself as a hero by the group he created. The tea, the "União do Vegetal” begins to mean the light of wisdom and the profound union with nature by those who share it, creating a new sacred movement. 


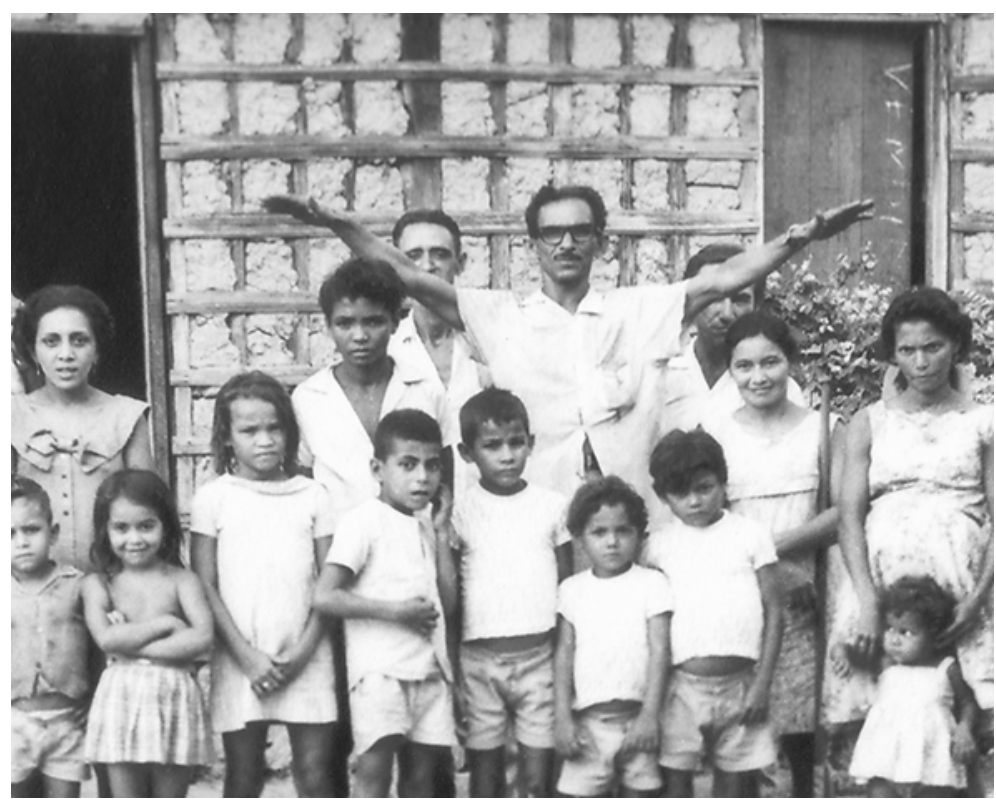

Photo 3 - Mestre Gabriel (with open arms) in Porto Velho, the 60s. Source: www.udv.org.br, 2015.

\subsection{Time and Network - União do Vegetal, from Porto Velho (RO) to Brasilia (DF)}

The first headquarters of the "União do Vegetal" (UDV) established in Porto Velho (Rondônia) will be "transplanted” to Brasilia, the city where Mestre Gabriel died in 1971, and reveals both the central symbolic point of view - space the death of the founder, "center" of the country - as the strategic point of view - the joint in the UDV performance networks.

The term "network" takes on a polysemic and historical character, used both by common sense and by different fields of science. According to Dias and Silveira (2005), the network attracts attention by assuming the character of organizational form from space by changing the territorial configurations through innovative material techniques that include groups, institutions or firms; conurbations and the political and economic sphere. Castells (1999, p. 497) states that networks "constitute the new social morphology of our society, and the diffusion of networking logic substantially modifies the operation and outcomes of processes of production, experience, power and culture”.

In this sense, the União do Vegetal (UDV), characterized by the ritual use of "Hoasca" since its formation was already presented by "paths" and "networks". However, here it is not a network in which circulate goods and services, but the organization of an immaterial and imagined territory that overlaps the territory of the material practices, that uses technological possibilities of modernity. They are immaterial goods that circulate in the network, creating a real "psychosphere, realm of ideas, beliefs, passions and place of production of meaning, providing rules to rationality or stimulating the imagination” (SANTOS, 1997, p. 204). 
Since the trajectory of its founder to the structuring of religion itself, in the city of Porto Velho in 1961, today has established itself as a Brazilian religion and has its administrative center in Distrito Federal. It is a migrant religion in a city of migrants; a religion originating from "cultural blends" - indigenous, cabocla, Northeastern - in a fundamentally “multicultural” city, but raised primarily by Northeastern. The UDV, with its global headquarters in Brasília, began to propagate its project of world through social, natural and spiritual practices, fundamentally reticular.

The expansion of this religious society takes from the territory meant as sacred, using material techniques to effect expansion and maintenance, present in all regions of Brazil, including abroad.

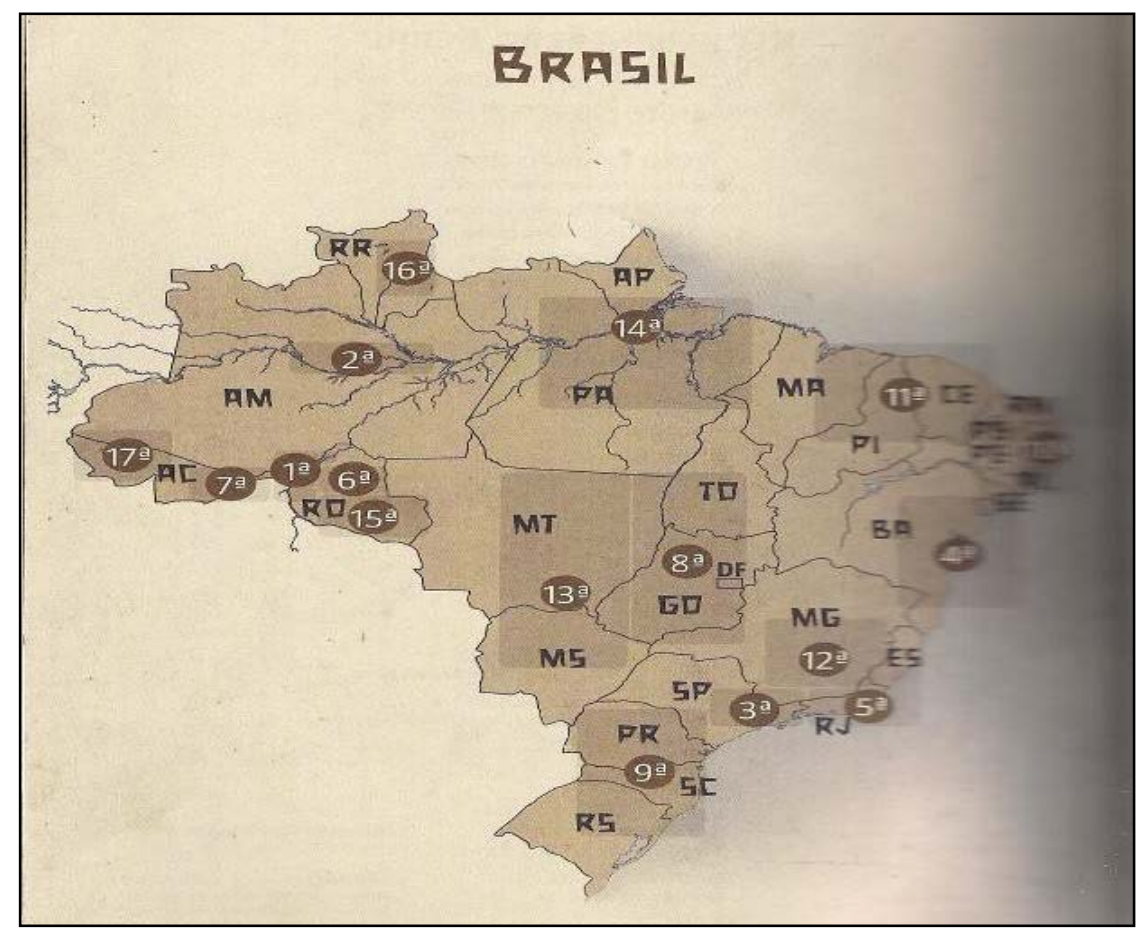

Figure 3 - Map of Brazil per Regions of UDV. Source: Institutional Schedule/Luis Neto and Ricardo Gallina Martis de Deus

The expansion occurs because the religiousness - not exactly the religion - enables the human being to exercise a reflection of "elements that model the world as the gods, spirits and rituals” (Campbell, 2013, p. 12). The human being, contrary to what was expected with the "desecration of the world" in recent centuries, is willing to withdraw from his worldly experience another experience, which could be called “transcendental” to address to God or to some religious belief.

When talking about networks we cannot neglect territories, which would be the mainstay and the substance of the networks, and as discussed above, social networks are organizing individuals or groups, involving the movement of relationships and opportunities. The territory, a 
taken and dominated space by individuals or groups can shape a particular identity, in this particular case, a religious identity.

The mode of operation and presence of the UDV religious society in the territory is articulated through social networks which, in turn, will territorializing new spaces, manifesting itself by a united labor and social movements, executed on the group’s territory (the nuclei then constituted, meeting spaces to perform its sacredness), and outside it, with activities such as "The day of kindness” fundraising campaign and distribution of warm clothing to vulnerable segments of the population, "Light of Knowledge" (youth, adults and seniors literacy), cultural activities (concerts and lectures of interest to the community) and health care. By crossing "nodes", the symbolic and cultural representations, by allowing an action, mobilize, sustain and streamline the sacred territory. In this sense, it constitutes a "transterritoriality" as write Goetterd, Modardo and Mota (2010) for individuals who are part of the UDV and also shapes up one transterritorial religious identity.

Networks of UDV constitute the construction of a social space, a charitable space in which its members perform an action that is stated in the social context, not as a dogmatic religion, but permeable to communicability and the sense of neighborhood. It is a different form of relationship and territoriality in the large city of Brasilia, following the strategy of many contemporary religious movements that are building new narratives, which stresses the non-dogmatization (SCHERE, 2005, p. 43).

The UDV is also expressed by materials networks, building an alternative project narrative that serves as a bridge of communication and dissemination of new cultural codes, to narrowing of the natural dimension of the human being in the world. Events such as the Water Festival and the cultivation of permaculture are valued, and where the four elements of nature are sacralized, showing the union of Nature with the modern world.

In this sense, the world project of UDV is not expressed only in terms of space, but also time or, more precisely, in terms of unit of time and space, in that the space may be characterized as "the condition existence of these relationships that create time" (Massey, 2009, p. 90). Thus, even in Brasilia, a symbolic space of national modernity, conditions are created to live other times, most associated with Nature or to a mythological and religious past, complexifying the daily life of the Brazilian Capital.

Interesting to note how Brasilia in its spatialized modernity creates conditions for the formation of religious and mythological relations and ways of living other times, other than the modern-urban. There are territories and social groups of networks that are manifested in mythical practices in which one lives in timeless mythical time that occurs in a modern time-space. Current 
religious practices in Brasilia interpret their subjective time as timeless, bringing and giving new meaning to a mythological past belonging to a particular collectivity although universal and not only of the UDV, but of other religions and religiousness present in the Federal District, such as the "Vale do Amanhecer".

This resignification of time and space occurs by the appreciation of nature (although not well defined by the various religiousness), valuing the mysteries and secrets printed on it. Thus, after Nature sacralized and symbolized, the living spaces come back to enable certain respect for what is "natural", a kind of forgotten knowledge, perhaps in the modern era. As writes La Blache (2010, p. 20): "Remember that, in the human environment the symbols, specifically the social ones, acquired a guidance function and therefore of knowledge”.

So it can be said that time becomes a symbol that shows different ways to be used valid for men, such as anti-modern, natural, mythological, sacred, defining and structuring the continuity of events due to certain principles and spatial conditions that try to control, in accordance with the structuring of territories and their networks. Mythology of the UDV reflects this form of differential relationship with time and even with the very nature almost in opposition to Brasilia modernism, as the capital represents the "man of knowledge", which represents the time as a kind of symbolism logical-mathematical in the different activities performed daily. Faced with this spatialized and accepted representation, certain groups, such as the UDV, emphasize the time of myth and mysteries, with greater subjectivity and involving elements of nature and allow a more holistic and contemplative relationship.

The logical-mathematical symbolism, however, also relies on myths for the appropriation of the territory and to recreate the sense and meaning of nature and the city where the denial of the ancient time is there to create a new history.

\section{4 - MEETING BETWEEN BRASILIA AND PRE-EXISTING SPACE}

The construction of Brasilia takes place in an extremely articulated discursive base modernist, conquering, monumental - in its planning and architecture, paradoxically rational in its execution and mystical in its territorial composition, as Siqueira (. 2003, p 39) highlights:

Brasilia was born from two great myths of creation: the Utopian City and the Promised Land. The first is inscribed in urban planning and futuristic architecture of its Pilot Plan, which has the shape of an airplane [...] and the other converges with the mystic in the prophecies of Don Bosco, which became even patron of the city.

Siqueira (2003) emphasizes the time - past and future - essential for understanding the spatiality of the Federal Capital and territorial experience enhanced by the utopia of the new city. 
But a utopia of the new must deny the previous conditions on which it is based, as the men who built it did so from elements freely chosen by them.

The space that today conforms what we know as Brasilia has a history dating back to the colonial Brazil, however, the discourse that seems to prevail in the official ideology is that of a nonexistent geographic area before the construction of the New Capital Federal, or no more than one spatiality in latency, waiting to be appropriated.

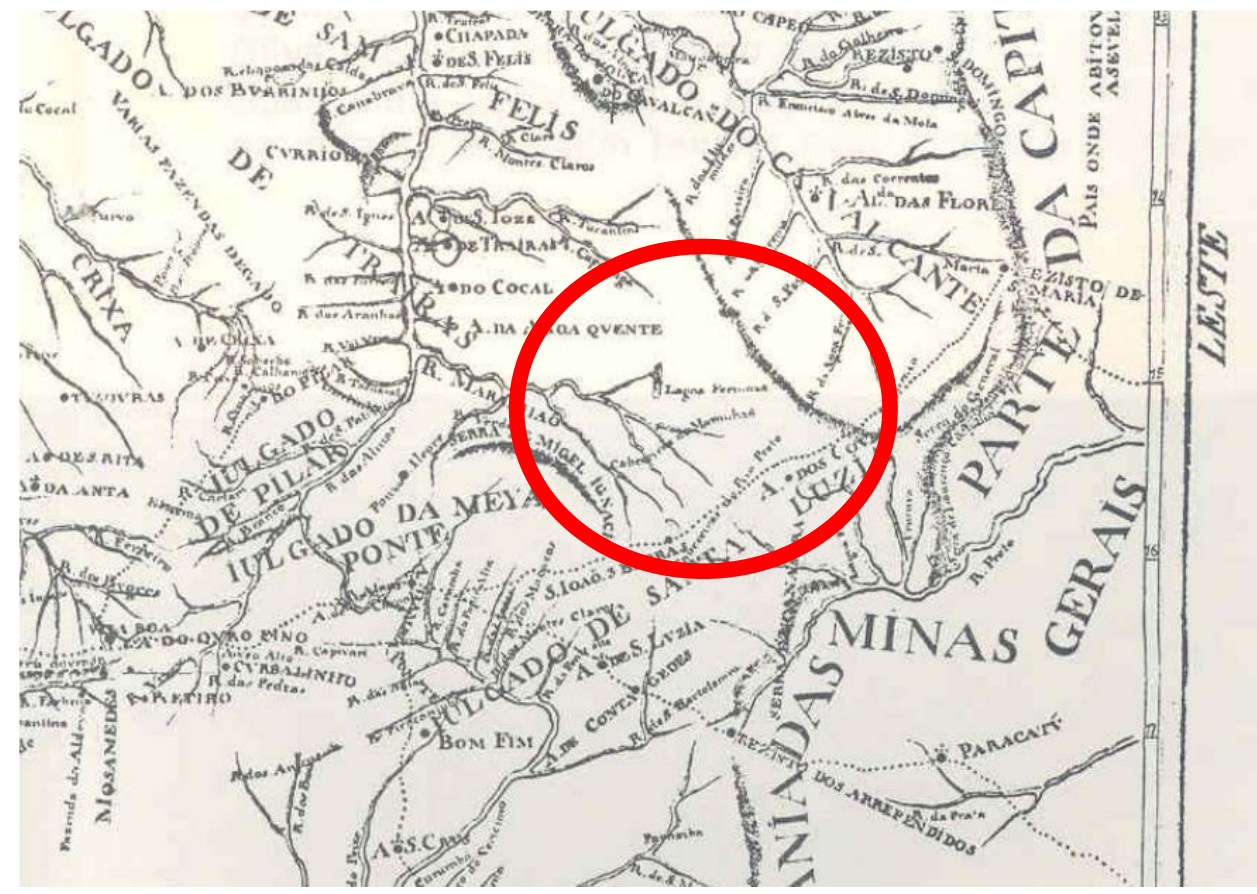

Figure 4 - Fragment of "Mapa dos Julgados" - a part of the map which includes the Julgado de Santa Luzia and the Julgado de Três Barras, bounding historical locations in the Distrito Federal. Circled in red is the approximate area where the capital would be built. Source: Vieira, Jr., 2009, p. 8.

The construction of Brasilia suggests the idea of victory against Brazil's interior, that is the defeat of slow time (SANTOS, 2004), which did not suit the march of modern and of glimpse of nationality that was heading towards a glorious future. However, the new capital was built on old territories, covered by several people already before history, including indigenous peoples who inhabited the Brazilian savanna since at least 10,000 years (Vieira Jr, 2009); more recently, quilombolas, former slaves (Magalhães, 2010) and even the countryman descendant of pioneers such as Anhanguera, so many times cited by Juscelino Kubitschek. Forgot, the dominant narrative, that the inside of the Brazilian territory had been trodden by expeditions and even more recent colonization movements, such as the March to the West, in the 1930s, on which the transfer of the old capital, City of Goiás to the planned Goiânia was a reference and in a way, opened the way for Brasilia. Thus, the definition of the area - milestones of the quadrilateral - of the Distrito Federal has a historicity, however, denied by the modernizing discourse of the 1960s. Accordingly, the 
official history of the hinterland resembles the "land without men" of Amazonia in the eternal return of the myth of progress.

According to Vieira Jr (2009, p. 12), the construction of Brasilia indicates a new phase of colonization, after the period of mining and agriculture.

Into nothing the city-capital could not have arisen, but the speech given by its builders returned to the backwoods logic, a far away and uninhabited place. As in previous pioneers, Brasilia sought to colonize Goiás hinterland, and as a downpour in the Cerrado valleys, modernity arrived in the 60s, resignifying as absence and delay time and forming relations of life in the sprawling plains of the Brazilian Central Plateau. Rich is the colonial history of Brasilia.

From this conception, one can also distinguish a double-sided colonial and imposing in the national ideals, which, when refusing or neglecting the previous history of the territory of the Distrito Federal, it creates the basis for the determination of what must be considered history that is due to the "construction of the new". Added to this, that Brasilia also starts to "determine the future” from the idea of progress it represents. Finally, the emergence of Brasilia is the culmination of a modernity project designed to Brazil in the 1960s. The conclusion of the construction of the New Capital, in the middle of “nothing” in Goiás hinterland, is the confirmation of technique over Nature.

From this perspective, Fischer, cited by Vieira Jr (2009, p. 12) states that

Archaism and modernity are mixed in Brasilia. And its history continues to be written in the record of the myth, presented as the first occupation of a virgin site, erased the traces of several centuries of the history of Goyaz, now apparently without past or own traditions, forgotten those who lived here before its construction. Thereby eliminating both its obvious imperfections as its undoubted qualities, the myth requires the consecration of its first conception - magically, the city merges with text and sketches that gave genesis.

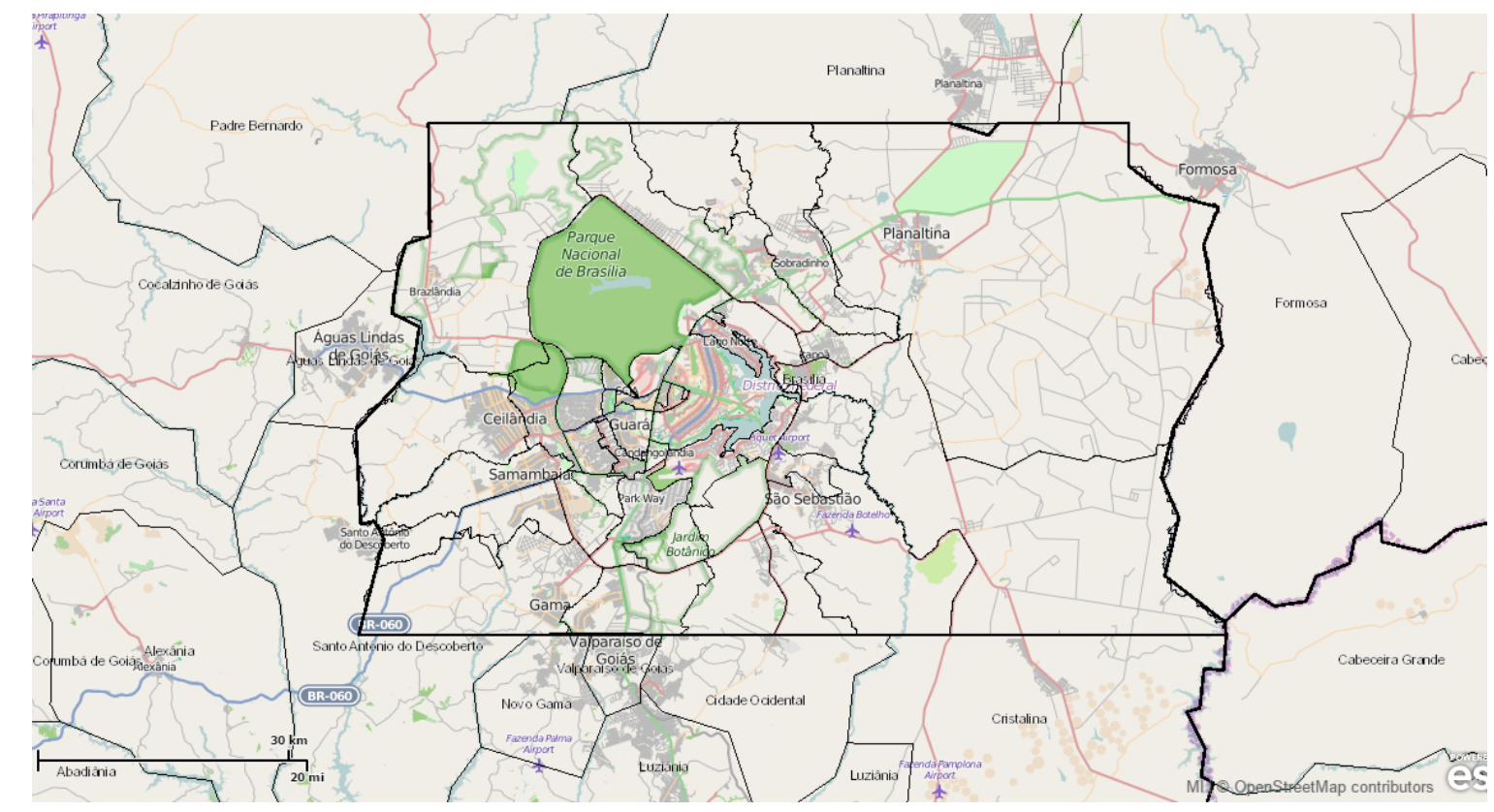


Map 3 - The Distrito Federal, with the Pilot Plan of Brasília and the administrative regions. Author: Pantoja, using the ODR, Ministry of Integration, 2015.

The sacralization of Brasilia does not happen magically just in text and sketches, however, spatially it materializes in the affirmation of a Pilot Plan that assumes the role of subject of history. To achieve this goal, groups and existing individuals are erased in favor of a nation's future unit, causing people who built and (re)construct it daily, are minor parts in the context of the conceived, the perceived and represented nationally. With the harmony of forms is intended the harmony of the national territory project of future, linked to all and effected by "docile bodies” (Foucault, 1992) from the center.

\section{5 - FINAL WORDS: THE MYTH RETURNS IN THE MODERN ERA}

The relationship between space and nature require an interpretation of human time not only chronological and chronometric, given that the spatial organization of processes in societies are made, largely by mythologies (despite all rationality that dives into the shadows). Myth is not simply a collectively shared belief, it is a force that nourishes the idealization that the subjects and institutions make of the real, both to support life and create new world projects. Geertz (2001, p. 155) already teaches us that "the world not only works with beliefs. But it can hardly function without them”.

As completion of the analysis that work with modernity, myth and symbol can do the reverse path of the heroes and starting from Brasilia, as Federal Capital and decision-making center of the country. Brasilia therefore assumes the role of subject of history because it was the place where the Trans-Amazonian was imagined as a land without men with any history to be taken and integrated into the national territory.

The forgetfulness of former rubber soldiers, replaced by new Trans-Amazonian soldiers is denied by the trajectory of Master Gabriel and his death in 1971, before the big road construction project, where Nature is an obstacle to be constantly beaten and constantly returns with its strength. The Plant mythical comes from the center of the forest to the capital of modernity, with a mission to unite people and nature. Brasilia, Capital of the Third Millennium, thus, presents itself as the center of a network whose mission is to expand the anti-modern, the natural, the mythological, the sacred coming from the shadows of the times and of the ancient heroes, who always return.

The theme developed in relation space / time with myth and heroes in modern times, the return to the past to understand "the incessant reactions of the history of geography”, as postulated by the founders, is a challenge for our science, which is very focused on the present and future 
predictions. Deepen over past brings surprising and important answers as a method to study the geographic space in its various manifestations.

\section{ACKNOWLEDGMENTS}

We thank the PhD studants Cleison Leite Ferreira (POSGEA - UNB) and Lidia Rogatto e Silva (CDS- UNB), respectively, for the English version of the abstract/article and the French version of the abstract.

\section{REFERENCES}

ALTHUSSER, L.. Posições I/Althusser. Rio de Janeiro: Edições Graal, 1978.

CAMPBEll, J. A Saga do Herói. In: COUSINEAU, P. (Org.). A Jornada do Herói - Joseph Campbell - Vida e Obra. São Paulo, Ágora, 2013.

CASTELLS, M. Sociedade em Rede. Vol. 1. São Paulo: Paz e Terra, 1999.

CLAVAL, P. Qu'apporte l'aproche culturelle a la geographie? Géographie et Cultures. La posmodernité. In Geographie et cultures, nº 33, été 1999.

. A Geografia Cultural. Florianópolis: Editora da UFSC, 1999

CUNHA, E. À Margem da História. Original de 1904. In: Biblioteca Virtual do Estudante Brasileiro. São Paulo: USP, s/d. Disponível em: http://www.superdownloads.com.br/download/124/margem-da-historia-euclides-da-cunha/, acesso em 05.07.2014.

DIAS, L. C.; SILVEIRA, R. L. L.. Redes, sociedades e territórios. Santa Cruz do Sul: EDUNISC, 2005.

ELIADE, M. O Mito do Eterno Retorno. São Paulo: Mercuryo, 1992.

FABIANO, R. O mensageiro de deus. Editora Pedra Nova, 2012.

FIGUEIREDO, L. C. Os Lugares da Psicologia. Palestra de Abertura da Semana de Psicologia. São Paulo: PUCSP/USP/UNIP, 1993.

FOUCAULT, M. A verdade e as formas jurídicas. São Paulo: PUC, 2002.

.As Palavras e as Coisas. São Paulo: Martin Fontes, 1992.

. Arqueologia do saber. Rio de Janeiro: Editora Forense Universitária, 1987.

. Microfísica do poder. Rio de Janeiro: Edições Graal LTDA, 1984.

GEERTZ, C. Nova luz sobre a antropologia. Rio de Janeiro: Jorge Zahar, 2001. 
GOETTERD, J. D.; MODARDO, M. L.; MOTA, J. G. B. Do choque de territorialidades à produção de transterritorialidades: encontros/desencontros identitários entre latifundiários e indígenas no Mato Grosso do Sul. In: Anais ENG 2010. Disponível em: www.agb.org.br/evento/download.php?idTrabalho=4497, acesso em 12.08.2014.

HAESBAERT, R.; PEREIRA, S. N.; RIBEIRO, G. (Orgs). Vidal, Vidais. Textos de Geografia Humana, Regional e Política. Rio de Janeiro: Bertrand do Brasil, 2012.

HAESBAERT, R. Vivendo no limite: dilemas do hibridismo e da multi/transterritorialidade. Niterói: UFF, 2009, 21 p.

HALL S. A identidade cultural pós-modernidade. 9 ed. Rio de Janeiro: DP \&A, 2004.

HONDA, Y.; SÊPEDA FILHO, M.; PANTOJA, W. W. R. As Diversas formas de Planejar o Espaço Amazônico: Um Olhar sobre Pacajá (PA). In: IV Colóquio Organizações, Desenvolvimento e Sustentabilidade, 2013. Disponível em: http://www.unama.br/seer/index.php/coloquio/article/view/108, acesso em 05.06.2014.

JASPERS, K. Introdução ao Pensamento Filosófico. São Paulo: Cultrix, 1993.

LA BLACHE P. Princípios de geografia humana. 3 ed. São Paulo: Tempo, 2010

MAGALHÃES, L. R. Sertão Planaltino: cultura, religiosidade e política no cadinho da modernização (1950-1964). Tese de doutorado (UFG - Faculdade de História), 2010. Disponível em: <http://pos.historia.ufg.br/uploads/113/original_1_pdfsam_tese.pdf> acesso em 05/07/2014

MASSEY D. Pelo espaço Rio de Janeiro: Editora Bertrand Brasil, 2009

MAUÉS, R. H. O Perspectivismo indígena é somente indígena? Cosmologia, religião, medicina e Populações rurais na Amazônia. In: Mediações. Dossiê Amazônia: Sociedade e Natureza. v. 17, n. 1, $2012 . \quad$ Disponível em: http://www.uel.br/revistas/uel/index.php/mediacoes/article/view/2012.v17n1p33/10987, acesso em 05.07.2014.

MENDOZA, J. G.; JIMENÉZ, J. M.; CANTERO, N. O.. El pensamento geográfico. Estudio interpretativo y antologia de textos (De Humboldt a las tendências radicales). Madrid: Alianza Editorial, 1982.

MERLEAU-PONTY, M. Fenomenologia da Percepção. São Paulo: Martin Fontes, 1999.

NAHUM, J. Região e Representação: A Região Amazônica nos Planos de Desenvolvimento. In: Revista Bíbliografica de Geografia e Cíencias Socieales, v. XVII, n. 985, 2012. Disponível em: http://www.ub.edu/geocrit/b3w-985.htm, acesso em 05.06.2013.

OLIVEIRA, J.K. Brasília trará equilíbrio à Nação Brasileira. In A Noite, 18/03/1957, $1^{\circ}$ Caderno, p. 5.

PELUSO, M. L. Reflexões sobre o ambiente urbano e representações sociais. In PAVIANI, A; GOUVÊA, L. A. de C. (orgs) . Brasília: controvérsias ambientais. Brasília: Editora UnB, 2003, p. 181-196. 
SANTOS, M. A natureza do espaço. Técnica e tempo/ razão e emoção. São Paulo: Hucitec, 1997.

. Por uma Geografia nova. São Paulo: Hucitec, 1990.

SCHERE, I. Redes, Sociedade e Territórios. Editora: Unisc, 2005.

SIQUEIRA, D. As novas religiosidades no Ocidente: Brasília, cidade mítica. Brasília: Edunb, 2003.

SOUZA, C. A. M. A morte é fácil na amazônia[?]: debates sobre epidemias e políticas públicas na construção da rodovia Transamazônica. In: Anais do Primeiro Seminário de Ecologia Humana e Sociologia da Saúde. 2010.2 Disponível em: http://seminarioformprof.ufsc.br/files/2010/12/SOUZA-C\%C3\%A9sar-Augusto-Martin s-de2.pdf, acesso em 04.07.2014.

VIEIRA Jr, W. Nos sertões cerrados de Brasília: a cartografia como argumento para releitura da história do Distrito Federal. In: Anais do III Simpósio Luso-Brasileiro de Cartografia Histórica. Disponível em: <https:/www.ufmg.br/rededemuseus/crch/vieira_jr_nos-sertoes-cerrados-debrasilia-a-cartografia-como-argumento.pdf.> acesso em 05/07/2014

WEBER, M. Três tipos puros de poder legítimo. Tradução: Artur Morão. In: www.lusofia.net, 2005. Disponível em: http://www.lusosofia.net/textos/weber_3_tipos_poder_morao.pdf, acesso em 04.07.2014. 